Journal of Applied Pharmaceutical Science Vol. 6 (08), pp. 142-150, August, 2016

Available online at http://www.japsonline.com

DOI: $10.7324 /$ JAPS.2016.60822

ISSN 2231-3354 (cc) BY-NC-SA

\title{
Liposomal Microencapsulation of Rodent-repelling Agents onto Jute Burlaps: Assessment of Cytotoxicity and Rat Behavioral Test
}

\author{
Ahmed A. Nada ${ }^{1}$, Ahmed G. Hassabo ${ }^{1}$, Amina L. Mohamed ${ }^{1}$, Marwa M. Mounier ${ }^{2}$, Nabil Y. Abou Zeid ${ }^{1}$ \\ ${ }^{1}$ National Research Centre, Textile Research Division, Pre-treatment and Finishing of Cellulosic Fibers Department, El-Behouth St. (former El-Tahrir str.), \\ Dokki, P.O. 12622, Giza, Egypt. ${ }^{2}$ National Research Centre, Pharmaceutical and Drug Industries Division, Pharmacognosy Department, Drug Bioassay- \\ Cell Culture Laboratory, El-Behouth St. (former El-Tahrir str.), Dokki, P.O. 12622, Giza, Egypt.
}

\begin{tabular}{|c|c|}
\hline ARTICLE INFO & ABSTRACT \\
\hline $\begin{array}{l}\text { Article history: } \\
\text { Received on: } 21 / 04 / 2016 \\
\text { Revised on: } 10 / 06 / 2016 \\
\text { Accepted on: } 30 / 06 / 2016 \\
\text { Available online: } 30 / 08 / 2016 \\
\end{array}$ & $\begin{array}{l}\text { In Egypt, the world's biggest wheat importer, about } 7 \text { to } 10 \text { percent of stored grains are damaged because of } \\
\text { poor conditions of storage. Rodent invasion is considered as one of the main reasons that caused wheat grain } \\
\text { damage. With respect of food safety, this work aims to treat the grain burlaps (containers) to rodent repellent. } \\
\text { The rodent repellent agents was extracted from natural local resources. For the rodent repellent effectiveness, } \\
\text { wheat burlaps are treated with rodent repelling agents using eco-friendly components. There are prepared using }\end{array}$ \\
\hline $\begin{array}{l}\text { Key words: } \\
\text { Liposome; } \\
\text { Microencapsulation; rodent } \\
\text { repellent, Functional coatings; } \\
\text { Jute burlaps. }\end{array}$ & $\begin{array}{l}\text { camphor oil, mint oil, and capsaicinoids (extracted from hot red pepper) as local resources to develop low cost } \\
\text { and high-performance final product. The plan of work relies on two main axes; first, the experimental part in } \\
\text { which burlap was treated for rodent repellent; second, testing and characterizing the treated samples for } \\
\text { cytotoxicity and animal behavior test. The treatment was taking place by conventional pad-dry-cure technique. }\end{array}$ \\
\hline
\end{tabular}

\section{INTRODUCTION}

Cellulosic fibers are natural polymers of vegetable origin, like cotton, linen, jute, ramie, and sisal.(Mohamed and Hassabo, 2015; Visakh and Arao, 2015)It would be useful to impart high performance properties to natural fibers to functionalize the natural fibers e.g. deposition and/or infiltration of functional polymeric materials onto/into the fiber surface, (Abo-Shosha et al., 2009; El-Zawahry et al., 2016; Ibrahim et al., 2013; Mohamed et al., 2016; Mohamed et al., 2013; Mohamed et al., 2013; Waly et al., 2009; Waly et al., 2012) using nanotechnology while preserving the inherent properties of the

\section{* Corresponding Author}

Ahmed Gomaa Hassabo, National Research Centre (Scopus affiliation ID 60014618), Textile Research Division, Pre-treatment and Finishing of Cellulosic Fibers Department, El-Behouth St. (former El-Tahrir str.), Dokki, P.O. 12622, Giza, Egypt.Emai: aga.hassabo@hotmail.com fiber, to modify the fiber surface by applying a nano-coating. (Hassabo, 2011; Hassabo, 2014; Hassabo et al., 2015; Hassabo et al., 2014; Hassabo et al., 2014; Mohamed et al., 2014). No one, these days, can deny the need for sustainable solutions of wheat related-issues in order to increase wheat production and decreasing the damage aspects. In terms of its importance in the Egyptian diet, wheat is the main winter cereal grain crop, planted over $32.6 \%$ of the total winter crop area and considered as a strategic commodity in Egypt. It is well known, wheat is basically consumed in form of bread that is produced at bakeries in big cities. The latter transported from warehouse to finally the bakeries. During this process, a huge loss of the grains, stored in burlaps mostly made of regular jute, is taking place. Unfortunately, Egypt, the world's biggest wheat importer, suffered crop damage up to 10 percent in most of the warehouses. In the rodent scope, rats and mice are considered as small animals. However, they grow radically in short time. 
Male-rats will reach about 275 grams in 2-3 months while female-rats will reach the same weight within 4 to 5 months. The problem is attributed to the small hole made by rodents to the whole grain burlaps. Such holes are the main reason of losing huge amounts of the whole grain during transportation and handling in processes. Add to that, broken grains by rodent's mouth are seriously dangerous for human use. What make matters worse, all attempts done for rodent control are failed, avoided and discovered by rodents. Less has been done for rodent repellent not even to the whole grain burlaps but only for coating the whole grain itself by treatment. Such treatment should consider the environmental impact of the treated materials (Nolte and Barnett, 2000).

The current work aims to produce effective treated jute burlaps with rodent repelling agents. Eco-friendly components were prepared using camphor oil, mint oil, and capsaicinoids (extracted from hot pepper) as local resources to develop low cost and high-performance rodent repellents. Liposomal microencapsulation was used to load jute fabrics with agents. Liposome microstructure was approved by florescent microscope. Coating was characterized by scanning electron microscope (SEM) and Fourier transform infrared spectroscopy (FTIR). The cytotoxicity test is done to examine the final product biocompatibility. Rat was used as animal model to test the animal behavior.

\section{EXPERIMENTAL}

\section{Materials and Methods}

Jute fabrics are provided in sheet $(60 "$ wide $\times 2$ Yard long) made out of $100 \%$ jute. 10 oz. per sq. yd. Sample are purchased from local market.

Mint oil, camphor oil and lecithin are purchased from local supermarket. Sodium hydroxide, gelatin granules (type A) and chloroform are purchased from Sigma Aldrich and are used without further purification.

\section{Capsaicinoids Extraction}

Capsaicinoids are the chemicals that give the burning sensation of hot pepper. They are present in almost every pepper (bell pepper, jalapeno, cayenne Pepper, etc.). Capsaicinoids are widely used in self-defense as a chemical agent spray for nonlethal weapon.

In chemistry view, capsaicinoids are the name given to the class of compounds and most of these compounds are $(\mathrm{N}$ vanillyl-8-methyl-6-(E)-noneamide) capsaicin (69\%) and dihydrocapsaicin (22\%) (Scheme 1). Capsaicinoids dissolve in organic solvents so that drinking water does not stop the burning (after eating) because the oil-based capsaicinoids will not dissolve in water. Much has been done in capsaicinoids extraction using organic solvents such as toluene (Wagner et al., 2011), acetonitrile (Huang et al., 2000), acetone etc. (Sass et al., 1977; Peusch et al., 1997)

However, Toluene was chosen as the preferred solvent for this experiment because it is more selective in the extraction of the capsaicinoids if compared with more polar solvents such as acetone (Wagner et al., 2011).
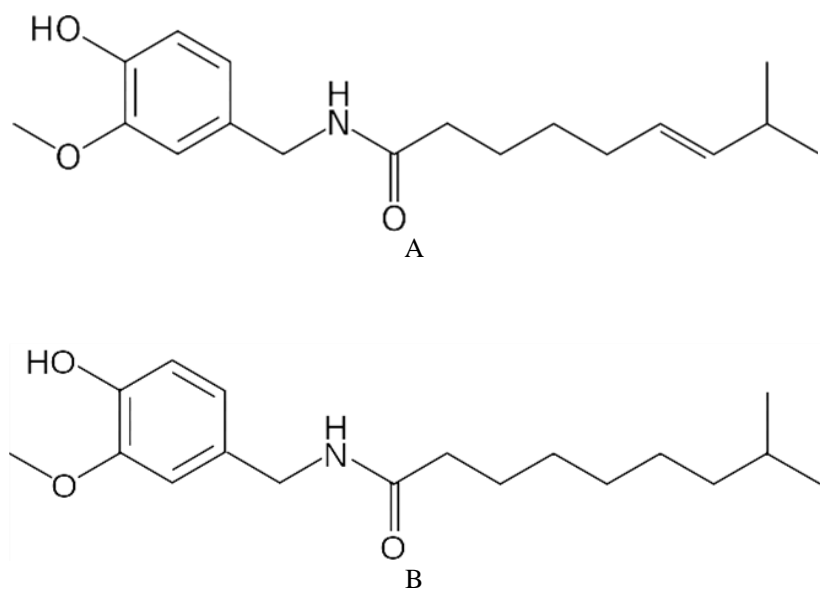

Scheme 1: Chemical structure of a) Capsaicin and b) 2-Dihydrocapsaicin

In typical procedure, washed, dried and chapped pepper (1 kg) was placed in a Soxhlet apparatus filled with $400 \mathrm{ml}$ toluene. Each patch was left for five times extraction before replacing the new patch. The extraction mixture was filtered through sintered-glass funnel and toluene was removed by distillation in a rotary evaporator. Gravity filtrationchromatography is used to separate the active components from organic toluene extract. In the chromatography column plugged with glass wool, fine silica gel $(60-120 \mu \mathrm{m})$ was used as stationary phase while a mixture of 3:1 hexane/ethyl acetate solvent was used as mobile phase. Fractions were collected and solvent was distilled in rotary evaporator. The yellowish greasy active component was stored at $4^{\circ} \mathrm{C}$ for further use.

\section{Preparation of the treatment emulsions}

In typical procedure, $(2 \mathrm{~g})$ lecithin was added to $1.5 \mathrm{~g}$ mint oil and/or camphor oil and/or capsaicinoids dissolved in 50 $\mathrm{ml}$ of chloroform in a $1 \mathrm{~L}$ round-bottomed flask. The mixture was stirred for $30 \mathrm{~min}$ at room temperature followed by addition of 50 $\mathrm{ml}$ of $5 \%$ gelatin solutions to the mixture and stirring was continued for more $30 \mathrm{~min}$ at $1500 \mathrm{rpm}$ at $60{ }^{\circ} \mathrm{C}$.

The milky suspension was concentrated under reduced pressure at $50{ }^{\circ} \mathrm{C}$ for $2 \mathrm{~h}$. The resulting dough was rehydrated with distilled water to adjust the solution volume to $60 \mathrm{ml}$. The emulsions were then sonicated for $2 \mathrm{~h}$ in ultrasonic bath (Fisher scientific, FS-21H). The resulting composite was stored at $40{ }^{\circ} \mathrm{C}$ for further use (Dastjerdi et al., 2010; Kumar and Katare, 2005; Paolino et al., 2002)

\section{Treatment of the Fabrics}

The jute fabrics were padded, in the previously mentioned emulsions containing one or more rodent repelling agents, to a wet-pickup of $100 \%$. Then it is air-dried. 


\section{Characterizations \\ Fourier transform infrared spectroscopy (FT-IR)}

Fourier transform infrared spectroscopy (FT-IR) tester of Nicolet Magna-IR 560 spectrometer was used to analyze the spectrum of the untreated and treated samples. $\mathrm{KBr}$ was used to prepare the samples. The tester collected transmittance of the infrared in the film between 400 and $4000 \mathrm{~cm}^{-1}$ are examined.

\section{Scanning electron microscopy (SEM)}

Treated fabrics morphology was investigated using scan electron microscopy (Quanta 250 FEG (Field emission Gun) after being coated with a layer of gold in vacuum using sputter coater S150A Edwards-England.

\section{Evaluation of treated fabrics}

\section{Tensile strength, rubbing test and surface roughness of jute} fabrics

Tensile strength and strain are carried out according to the ASTM Standard Test Method D-1682-1924(ASTM Standard Test Method C33 (ASTM D-1682-1924), 2011)on a tensile strength apparatus type FMCW 500 (Veb Thuringer Industrie Werk Rauenstein $11 / 2612$ Germany) at $25^{\circ} \mathrm{C}$ and $65 \%$ relative humidity. The results quoted are the mean of 5 breaks for the warp direction with test length of $20 \mathrm{~cm}$ at a constant breaking time of 20 seconds load scale $10-50 \mathrm{Kg}$. Surface roughness was monitored according to JIS 94 standard, using surface roughness measuring instrument, SE 1700, made in Japan.

\section{Abrasion test}

Abrasion tests (dry) were assessed according to standard methods (ASTM D-6279). This test method covers procedures for evaluating the relative use resistance of a sandpaper applied to fabric surface. Dry rub abrasion tests are carried out for 1000 cycles for sample with dimensions $(5 \times 20 \mathrm{~cm})$.

\section{Stiffness properties}

Stiffness was measured by using ASTM test method D 1388 - 96 using the cantilever apparatus (ASTM 1388 - 96, 2002) (ASTM Standard Test Method C33 (ASTM D-1388-08), 2012) Stiffness is a special property of fabric. It is the tendency of fabric to keep standing without any support. It is a key factor in the study of handle and drape of fabric. The procedure was carried out as follow: specimen is cut to size $15 \times 2.5 \mathrm{~cm}$ with the aid of the template. Both the template and specimen are transferred to the platform with the fabric underneath. Then both of them are slowly pushed forward. The strip of the fabric will commence to droop over the edge of the platform and the movement of the template and the fabric is continued until the tip of the specimen viewed in the mirror cuts both index lines. The bending length can immediately be read off from the scale mark opposite a zero line engraved on the side of the platform. Each specimen is tested four times, at each end and again with the strip turned over. Three samples are tested and mean values for the bending length in warp and weft directions can be calculated.

\section{Animal behavioral test}

The animal behavioral test was carried out according to the suggested design. However, Tigner et al suggested an idea for animal cage; therefore, a modified cage design was created as illustrated in Fig. 1 (Tigner and Besser, 1962).

All rats were handled in accordance with the NIH Guidelines for the Care and Use of Laboratory Animals and with the recommendations of the Institutional ethical committee (Reg. No. 15-223).

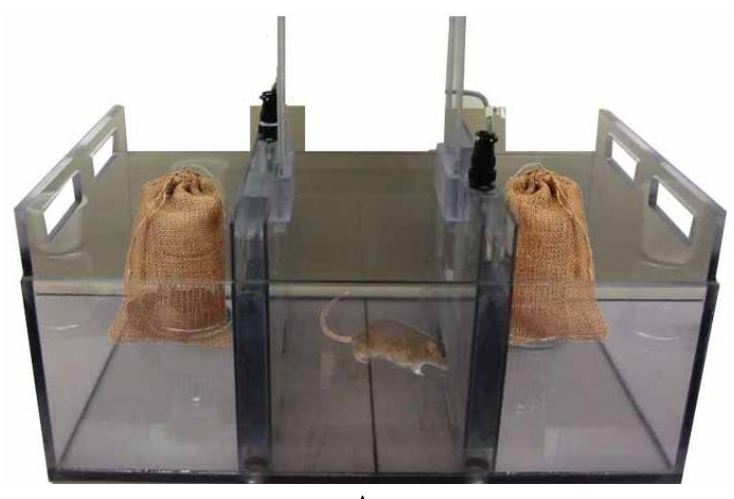

A

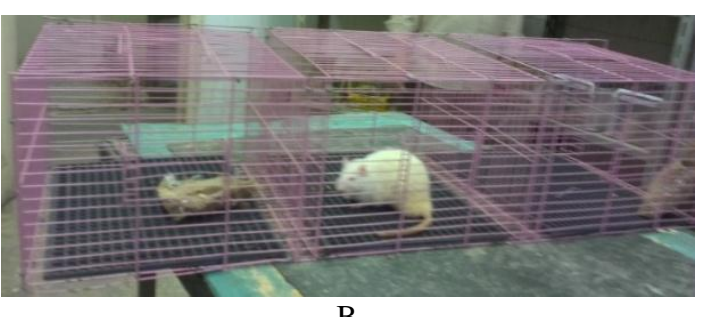

Fig. 1: Suggested (a) and house-made (b) testing cage of animal behavioral test for rats

\section{Cytotoxicity assessment}

This was done according to the procedure described by (Moustafa et al., 2014; Nada et al., 2015)with slight modification as described in details by (El-Menshawi et al., 2010; Mohamed et al., Accepted 2016). In typical procedure, cells were maintained in Dulbecco's modified eagle medium (DMEM):F12 Medium (nutrient mixture) $10 \%$ fetal bovine serum (FBS) and were incubated at $37^{\circ} \mathrm{C}$ in $5 \% \mathrm{CO}_{2}$ and $95 \%$ humidity. Skin normal human cell line (BJ-1) "A telomerase immortalized normal foreskin fibroblast cell line" cells were seeded into wells in 96well plate and at a density of 30000 cells per well. After incubation for $48 \mathrm{~h}$ the culture medium were replaced by extracted media of different concentrations (from 20000 to $100 \mathrm{ppm}$ $(\mu \mathrm{g} / \mathrm{ml})$ ) of the tested compounds (each sample was tested in 3 different wells). Samples were sterilized under ultraviolet (UV) light for $20 \mathrm{~min}$ in a laminar flow before extraction. Cell culture medium without additional reagents was used as a control. The plate was incubated again for $24 \mathrm{~h}$. The amount of living cells was determined by the MTT assay. The culture medium was aspirated and replaced by $40 \mathrm{ul}$ of MTT solution $(2.5 \mathrm{mg} / \mathrm{ml})$. Then, the solution was incubated for $4 \mathrm{~h}$ at $37{ }^{\circ} \mathrm{C}$. The solution was aspirated 
and $200 \mu \mathrm{l}$ 10\% sodium dodecyl sulphate (SDS) in deionized water was added to each well to dissolve the formazan crystals and incubated overnight at $37^{\circ} \mathrm{C}$. The absorbance was measured using a micro-plate multi-well reader at $595 \mathrm{~nm}$ and a reference wavelength of $690 \mathrm{~nm}$.Cell viability was calculated according to the following equation:

$$
\text { Cell viability }=\frac{\text { average }(X)}{\text { average }(N C)} \times 100
$$

where: X: absorbance of sample, NC: absorbance of negative control. Absorbance was measured at $595 \mathrm{~nm}$ with reference 690 nm.

\section{RESULTS AND DISCUSSION}

\section{Characterization of Capsaicinoids}

Fig. 2 shows the FT-IR spectra of capsicinoid, where the $\mathrm{C}=\mathrm{O}$ stretch of the amide group appears as a shoulder at $1660 \mathrm{~cm}^{-1}$ while N-H stretch and bending of the amide group appears at 3006 $\mathrm{cm}^{-1}$ (Huang et al., 2000)and at $1457 \mathrm{~cm}^{-1}$ (Tomasino, 1992) respectively. A broad peak was observed at $3445 \mathrm{~cm}^{-1}$ that may attribute to the $\mathrm{OH}$ of the phenol ring. (Wagner et al., 2011) However, the aromatic double bond and ether bond were observed at 1742 and $1163 \mathrm{~cm}^{-1}$ (Ibrahim et al., 2013) respectively.

Furthermore, fig. 2 shows the ${ }^{1} \mathrm{H}$ NMR spectrum of the Capsaicinoids. The chemical shifts are presented in the spectrum ( $\delta 0.8$ ppm (6H, Ho), $\delta 1.34$ ppm (2H, Hm), $\delta 1.47$ ppm (2H, Hn), $\delta 1.9 \mathrm{ppm}(4 \mathrm{H}, \mathrm{Hl}, \mathrm{k}), \delta 2.1 \mathrm{ppm}(1 \mathrm{H}, \mathrm{Hi}), \delta 2.4 \mathrm{ppm}(3 \mathrm{H}, \mathrm{Hh}), \delta$ 2.7 ppm (2H, Hg), $\delta 3.3$ ppm (2H, He,f), $\delta 3.9$ ppm (1H, Hd), $\delta 4.1$ ppm $(2 \mathrm{H}, \mathrm{Hc}), \delta 5.3 \mathrm{ppm}(1 \mathrm{H}, \mathrm{Hb})$, and $\delta 7.6 \mathrm{ppm}(1 \mathrm{H}, \mathrm{Ha})$. The characteristic hydroxyl proton of the phenol functional group and the amide proton were clearly observed at $\delta 7.6$ and $5.3 \mathrm{ppm}$ respectively. Some other peaks were observed in the regions $\delta 12$ and $7.2 \mathrm{ppm}$, which could be of the extraction residuals.
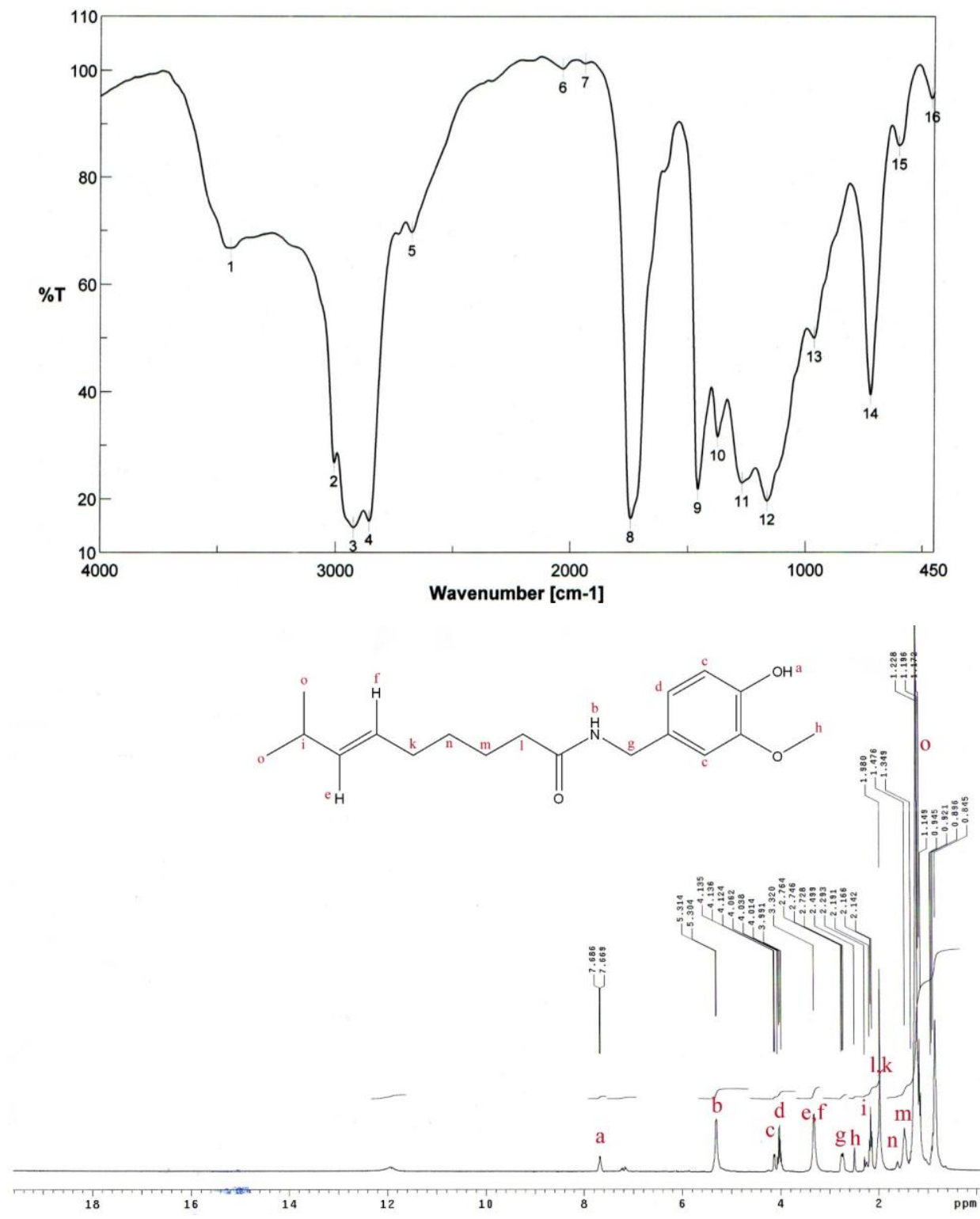

Fig. 2: FT-IR and ${ }^{1} \mathrm{H}$ NMR spectrum of extracted Capsaicinoid. 


\section{Preparation of Coating Emulsion and its Characterization}

Table 1 shows the recipes of the coating emulsions, which contain mainly two main components. Oil phase; which typically contains the phospholipid (surfactant) and the rodent repellent agents. However, the water phase contains the gelatin solution $(5 \%)$. The ratio of the phospholipids and the repelling agent was kept at 2:1.5. Such ratio was taken as a result of microscope images to different ratios till well distribution was observed via optical microscope (Fig. 3).

Typically, when lipid phase dissolves in chloroform and then dried via rotary evaporator, a thin layer of bilayer lipid was formed in the inside wall of glass flask. This bilayer contains the phospholipid and the repelling agents as shown in Fig. 4. Afterwards $50 \mathrm{ml}$ of $5 \% \mathrm{wt} / \mathrm{v}$ gelatin solution was added to produce the liposome form in which the repelling agent entrapped in the bilayer. The liposomal structure was approved by adding florescent substance that slightly soluble in chloroform into the lipid phase during the preparation process. Warm small amount of the emulsion was carefully spread onto microscope slide. Fig. 5 shows the florescence microscope images for the encapsulated agents inside the bilayer of liposome as a strong proof for the suggested macrostructure of the prepared emulsion.

Table 1: The preparation of the coating emulsions

\begin{tabular}{|c|c|c|c|c|c|c|c|}
\hline \multicolumn{8}{|c|}{ Coating emulsions } \\
\hline Sample & & 1 & 2 & 3 & 4 & 5 & 6 \\
\hline \multirow{2}{*}{ Lipid phase } & lipid & 0 & $2 \mathrm{gm}$ & $2 \mathrm{gm}$ & $2 \mathrm{gm}$ & $2 \mathrm{gm}$ & $2 \mathrm{gm}$ \\
\hline & Oil & 0 & 0 & 1.5gmCapsicinoid & 1.5 gm camphor oil & $1.5 \mathrm{gm}$ mint oil & 1.5 gm Caps., camph. and mint oil \\
\hline Water phase & & 0 & $50 \mathrm{ml} / 5 \%$ gelatin & $50 \mathrm{ml} / 5 \%$ gelatin & $50 \mathrm{ml} / 5 \%$ gelatin & $50 \mathrm{ml} / 5 \%$ gelatin & $50 \mathrm{ml} / 5 \%$ gelatin \\
\hline
\end{tabular}

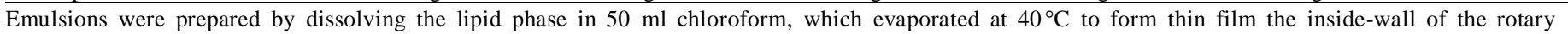
evaporator flask. $50 \mathrm{ml}$ of water phase was added to the flask till milky solution was formed. Emulsions were sonicated for 2 hrs.



Fig. 3: Light microscope image of particles in emulsion film.

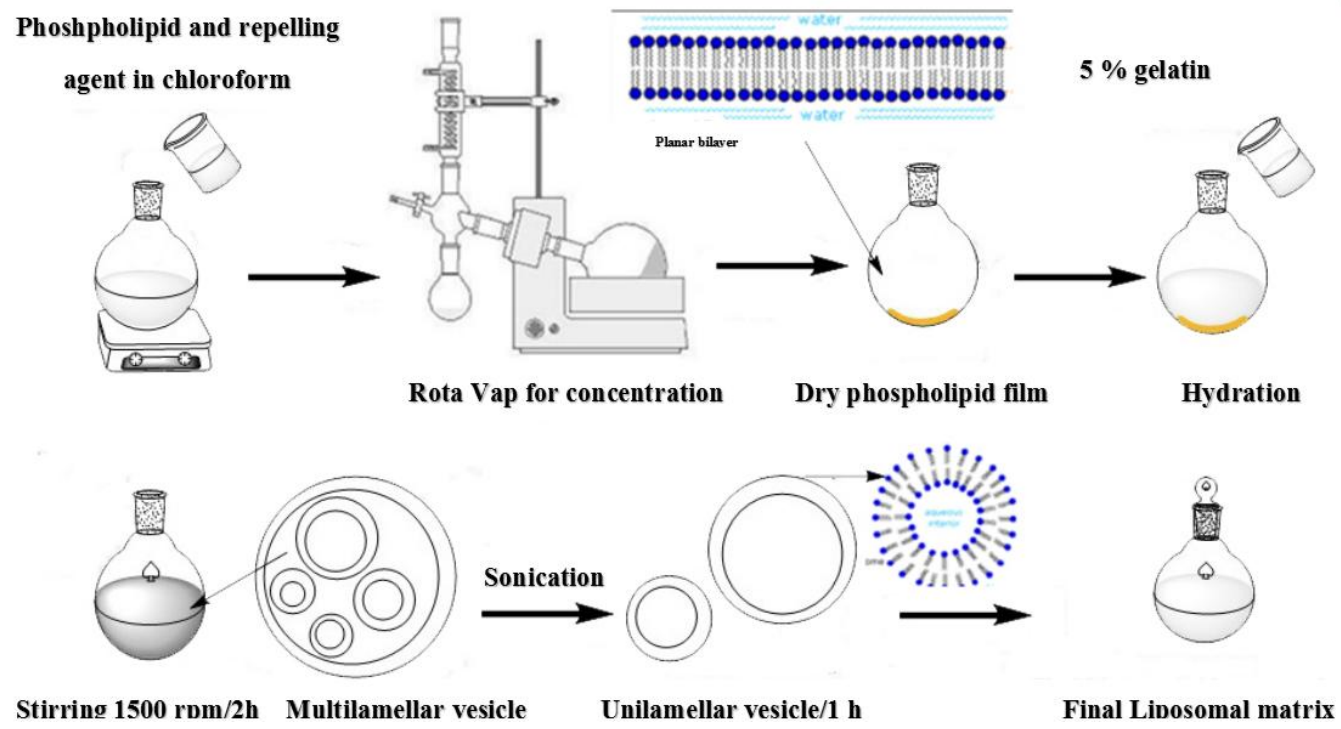

Fig. 4: Schematic diagram for the repelling agent liposomal/gelatin emulsions. 


\section{Fabric treatment and its morphology}

Samples of jute fabric in size of $20 \times 25 \mathrm{~cm}$, were padded in $50 \mathrm{ml}$ emulsion solution and squeezed in wet pickup $100 \%$. Samples were air-dried and used for further analysis.

Fig. 6 shows the SEM images of the untreated and treated samples. The typical morphology of the untreated jute fabrics is observed in Fig. $6(\mathrm{a}-\mathrm{c})$, and the treated jute fabrics in Fig. $6(\mathrm{~d}-\mathrm{f})$.
As expected, the surface of the treated jute fabrics exhibits very smooth surfaces while the untreated are not. All the treated fibers in the fabric structure appear homogenously covered by a continuously thin film Fig. $6(d-f)$. The most significant difference arises from the filling of the space between the fibers in fabric structure.

The most significant difference arises from the filling of the space between the fibers in fabric structure.
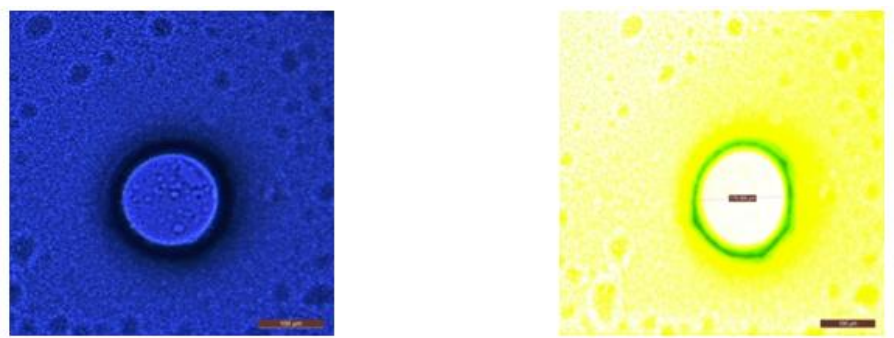

Liposomes diameter $175 \mu \mathrm{m}$
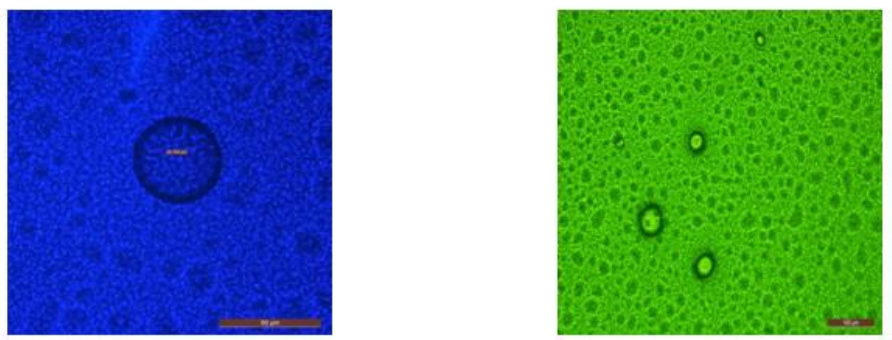

Liposomes diameter $42 \mu \mathrm{m}$

Fig. 5: Florescence microscope images for the encapsulated agents inside the bilayer of liposomes. Lipid phase was mixed with florescence dye during the preparation steps.
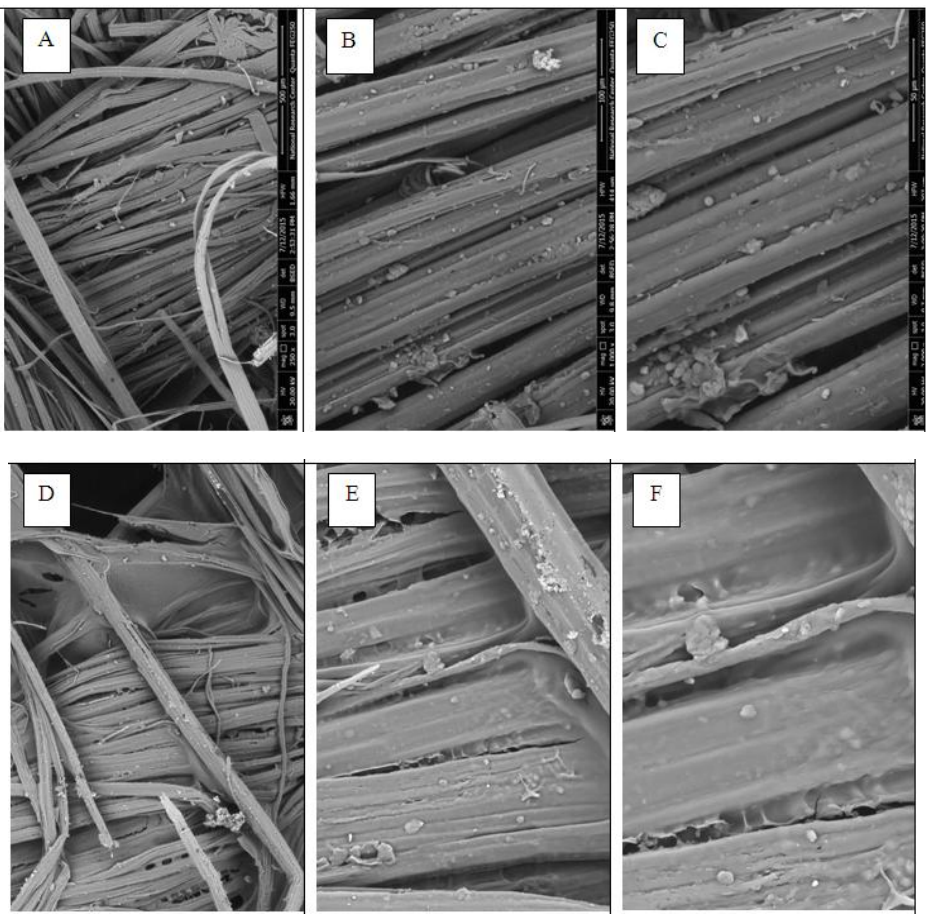

Fig. 6: SEM magnifications of untreated jute fabrics $(\mathrm{a}-\mathrm{c})$ and treated jute fabrics $(\mathrm{d}-\mathrm{f})$ Samples were treated with emulsion solutions with lipid content $17 \%$, wet pick up $100 \%$, and air-dried. 


\section{FT-IR analysis for jute fabrics}

Fig. 7 shows the FT-IR spectra for untreated and treated jute fabric with only capsicinoids emulsion and with all repelling agents together. Spectral data shows a typical fingerprint spectrum for jute fabric with strong board band for $\mathrm{OH}$ groups at the region of $3000 \mathrm{~cm}^{-1}$ and other strong peaks at $1400 \mathrm{~cm}^{-1}$ represents the $\mathrm{C}$ $\mathrm{O}-\mathrm{C}$ bonds in the glucose units of cellulose in jute fabrics (Hassabo et al., 2015).

In addition, data shows that treated samples did not record any new peaks of new functional groups indicating that no chemical reaction has taken place in such coating process.

\section{Mechanical and physical properties of jute fabrics}

As the major materials for burlaps is jute, and these burlaps are used for storing wheat, mechanical properties of these burlaps should be not decreasing or changed to be suitable for storing. Therefore, it is important to study the mechanical properties. Table 2 shows the mechanical properties of the untreated and treated jute fabrics namely; tensile strength, strain and stiffness properties. In general, coating treatments improved the tensile strength to reach $150 \%$ for warp direction and $140 \%$ in the weft direction. Such increments may be attributed to the action of filling the space between fibers in the fabric structure as seen in Fig. 6.

However, the strain values of the treated samples slightly decreased in the warp direction to reach $80 \%$ and to reach up to $50 \%$ in the weft direction. Such decrease in the strain values translate the incapability of the treated samples to be stretched. The latter phenomenon is owing to the same reason of tensile strength, which is the action of filling the space between fibers.

In addition, Table 2 shows the samples stiffness represented by the bending length of untreated and treated samples. It is clear from data that all treated samples showed higher stiffness than that of untreated fabrics.

Table 2 shows the abrasion effect of the untreated and treated fabrics. Data shows that, using soft sandpaper, within 1000 rpm insignificant weight loss was recorded for the treated samples.

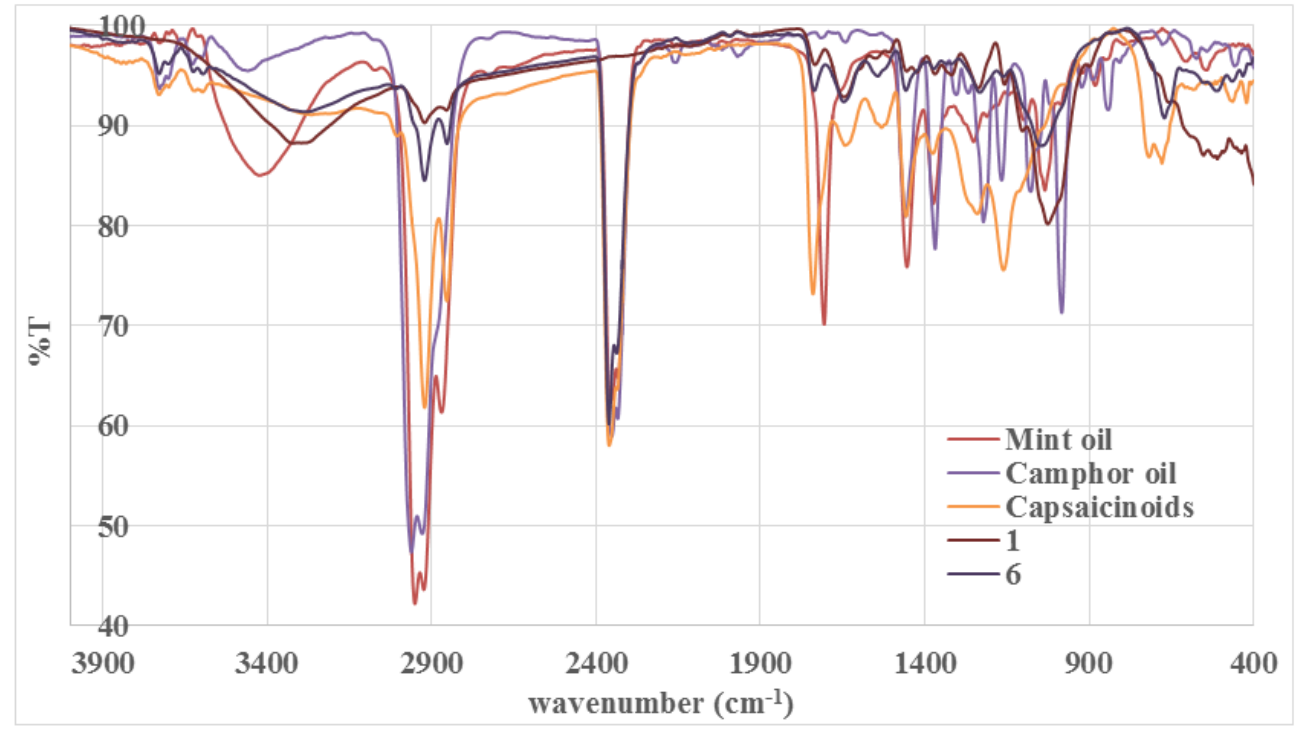

Fig. 7: FT-IR spectrum of untreated and treated jute fabrics Samples were treated with emulsion solutions with $17 \%$ lipid content, wet pickup $100 \%$, and airdried.

Table 2: Mechanical and physical properties of jute samples.

\begin{tabular}{llllllllll}
\hline & \multicolumn{2}{l}{ Tensile strength $(\mathrm{Kg})$} & Strain $(\%)$ & \multicolumn{2}{l}{ Bending length $(\mathrm{cm})$} & Abrasion & \\
\hline samples & warp & weft & warp & weft & warp & weft & Before $(\mathrm{gm})$ & after 1000 rpm (gm) & Loss in weight $(\%)$ \\
\hline 1 & 41 & 82 & 25 & 20 & 12.5 & 11.5 & 4.82 & 4.82 & 0 \\
2 & 86 & 150 & 22 & 10 & 0 & 0 & 5.10 & 4.99 & 0.11 \\
3 & 70 & 90 & 18 & 12 & 0 & 0 & 5.11 & 4.86 & 0.25 \\
4 & 55 & 120 & 20 & 4 & 0 & 0 & 5.13 & 4.80 & 0.33 \\
5 & 65 & 130 & 20 & 18 & 0 & 0 & 5.12 & 4.89 & 0.23 \\
6 & 69 & 105 & 18 & 15 & 15 & 15 & 5.15 & 5.12 & 0.03 \\
\hline
\end{tabular}

Samples of dimensions $2.5 \times 15 \mathrm{~cm}$ were tested. The results are quoted as the mean of 5replicates for the warp and weft directions and referred to sample codes given in Table 1 . 


\section{Cytotoxicity test}

Biocompatibility of the treated jute fabrics were demonstrated using skin normal human cell line (BJ-1) cell, viability and material toxicity (harmfulness) is characterized as greater than $30 \%$ cell death (Nada et al., 2014). Fig. 8 reveals that rodent repelling agent has insignificant adverse effect on cell viability especially with higher amounts $(40 \mu \mathrm{l})$.

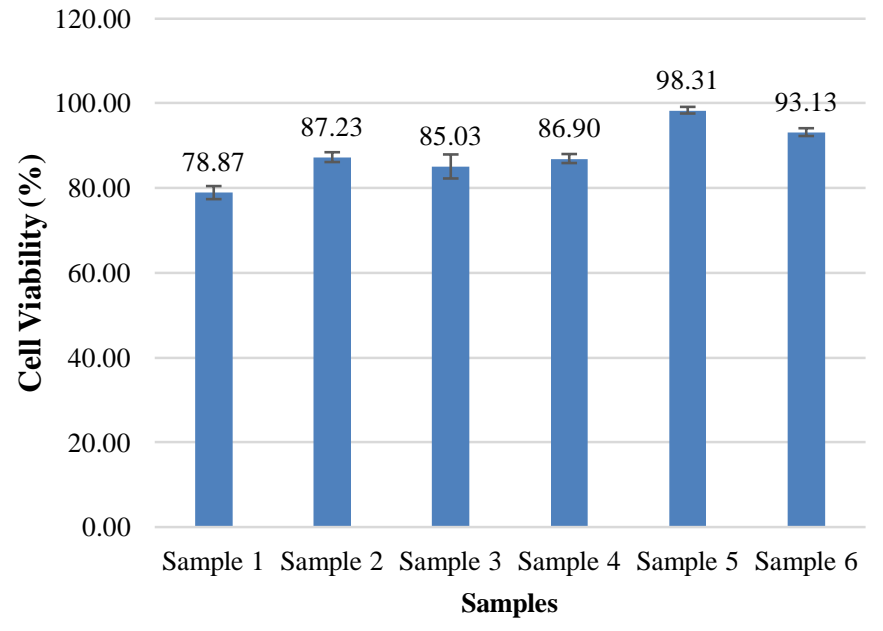

Fig. 8: Skin normal human cell line (BJ-1) cell viability in percentage with sample (untreated, with lipid, with capsicinoids, with camphor oil, with mint oil and with mixture of three rodent agents respectively)

Data also investigated the impact of the camphor and mint oil on cell viability. Results demonstrated that cell viability was enhanced upon adding the rodent agent in the treating composite. In addition, rodent agent showed nontoxic nature. Furthermore, mixture of three rodent agent shows good cell viability comparing to untreated one.

\section{Animal behavioral test}

Typically, rat (200 g, male rat) was hosted in the cage over night with regular feeding materials to be familiar with new cage. Next day, regular food was replaced with only untreated burlaps ( $4 \times 4$ inch) loaded with wheat. Only rats who recorded a good penetration to the burlaps were taken to the next step in the procedure.

Fig. 9 show the sequences for the test procedure. Rats were hosted in the middle box in the cage for $18 \mathrm{~h}$ to ensure that rat is hungry enough. Afterwards, the barriers between boxes in the cage were flagged up to allow rat to move freely in the whole cage and has free exposure to the untreated and treated samples.

Only samples treated with capsicinoids (pepper extract) were untouched comparing to a complete penetration to the untreated samples. However, burlaps, treated with other agents such as mint oil and camphor oil, were moved from its place with no penetration as well. Fig. 9c shows the penetration of untreated burlap.

Furthermore, Table 3 shows physical observation of the untreated and treated burlaps after $24 \mathrm{~h}$ of exposure. The data confirm that the treated sample with mixture of three oil did not touched or moved while the untreated one was touched, moved and penetrated. In addition, the other treated samples were moved from their place put did not touched from the rat teeth.


Fig. 9: Photography image of untreated and treated burlap $(4 \times 4$ inch) filled with wheat. a) Zero time of exposure, b) untreated after penetration ( $24 \mathrm{~h}$ of exposure) and c) treated after penetration ( $24 \mathrm{~h}$ of exposure).

Table 3: physical observation of untreated and treated burlap filled with wheat

\begin{tabular}{ccc}
\hline \multirow{2}{*}{ Samples* } & \multicolumn{2}{c}{ Physical observation } \\
\cline { 2 - 3 } & Moved & Penetrated \\
\hline 1 & $\sqrt{ }$ & $\sqrt{ }$ \\
2 & $\sqrt{ }$ & partially \\
3 & $\times \times \times \times$ & $\times \times \times \times$ \\
4 & $\sqrt{ }$ & $\times \times \times \times$ \\
5 & $\sqrt{ }$ & $\times \times \times \times$ \\
6 & $\times \times \times \times$ & $\times \times \times \times$ \\
\hline
\end{tabular}

* Refer to Table 1 for sample's composition.

\section{CONCLUSION}

Capsaicinoid as a rodent repelling agent was extracted from locally available hot pepper, purified and characterized via spectral analysis. Liposomal emulsions of microencapsulated rodent repelling agents were prepared based on gelatin and lecithin. Liposomal structure was confirmed using fluorescent microscope. Jute burlaps were treated with liposomal emulsions and examined for mechanical properties, cytotoxicity and animal behavioral test. Generally, treated samples showed very weak cytotoxicity on normal human cell line. For rat behavioral test, samples containing capsaicinoids showed excellent rodent repellency over mint and camphor oils.

\section{ACKNOWLEDGEMENT}

This work was financially supported by National Research Center, (Scopus afflitiation ID 60014618), project No. 10050501, El-Behouth St. (former El-Tahrir str.), Dokki, P.O. 12622, Giza, Egypt. 


\section{REFERENCES}

Abo-Shosha MH, Nassar FA, Haggag K, El-Sayed Z, Hassabo AG. Utilization of some fatty acid/PEG condensates as emulsifiers in kerosene paste pigment printing. Research Journal of Textile and Apparel, 2009; 13(1):65-77.

ASTM Standard Test Method C33 (ASTM D-1388-08). 2012. Standard test methods for stiffness of fabrics. West Conshohocken, PA: ASTM International.

ASTM Standard Test Method C33 (ASTM D-1682-1924). 2011. Standard test methods for determination of tensile strength. West Conshohocken, PA: ASTM International.

Dastjerdi R, Montazer M, Shahsavan S. A novel technique for producing durable multifunctional textiles using nanocomposite coating. Colloids and Surfaces B: Biointerfaces, 2010; 81(1):32-41.

El-Menshawi BS, Fayad W, Mahmoud K, El-Hallouty SM, ElManawaty M, Olofsson MH, Linder S. Screening of natural products for therapeutic activity against solid tumors. Indian J. Exp. Biol., 2010; 48(3):258-264.

El-Zawahry MM, Abdelghaffar F, Abdelghaffar RA, Hassabo AG. Equilibrium and kinetic models on the adsorption of reactive black 5 from aqueous solution using eichhornia crassipes/chitosan composite. Carbohydr Polym, 2016; 136:507-515.

Hassabo AG. 2011. Synthesis and deposition of functional nano-materials on natural fibres (Vol. PhD Degree, p. 154): RWTH Aachen University.

Hassabo AG. New approaches to improving thermal regulating property of cellulosic fabric. Carbohydr Polym, 2014; 101:912-919.

Hassabo AG, Erberich M, Popescu C, Keul H. Functional polyethers for fixing pigments on cotton and wool fibres. Research and Reviews in Polymer, 2015; 6(3):118-131.

Hassabo AG, Mendrek A, Popescu C, Keul H, Möller M. Deposition of functionalized polyethylenimine-dye onto cotton and wool fibres. Research Journal of Textile and Apparel, 2014; 18(1):36-49.

Hassabo AG, Nada AA, Mohamed AL, Abou-Zeid NY. Properties of cellulosic fabrics treated by water-repellent emulsions. Indian Journal of Fibre and Textile Research, Accepted 2015.

Hassabo AG, Schachschal S, Cheng C, Pich A, Popescu C, Möller M. Poly (vinylcaprolactam)-based microgels to improve gloss properties of different natural fibres. Research Journal of Textile and Apparel, 2014; 18(1):50-63.

Huang J, Mabury SA, Sagebiel JC. Hot chili peppers: Extraction, cleanup, and measurement of capsaicin. J Chem Educ, 2000; 77(12): 1630 .

Ibrahim NA, El-Sayed ZM, Fahmy HM, Hassabo AG, AboShosha MH. Perfume finishing of cotton / polyester fabric crosslinked with dmdheu in presence of some softeners. Research Journal of Textile and Apparel, 2013; 17(4):58-63.

Kumar R, Katare OP. Lecithin organogels as a potential phospholipid-structured system for topical drug delivery: A review. AAPS PharmSciTech, 2005; 6(2):E298-310.

Mohamed AL, El-Naggar ME, Shaheen TI, Hassabo AG. Novel nano polymeric system containing biosynthesized core shell silver/silica nanoparticles for functionalization of cellulosic based material. Microsystem Technologies, 2016; 22(5):979-992.

Mohamed AL, El-Sheikh MA, Waly AI. Enhancement of flame retardancy and water repellency properties of cotton fabrics using silanol based nano composites. Carbohydr Polym, 2014; 102:727-737.

Mohamed AL, Er-Rafik M, Moller M. Suitability of confocal raman microscopy for monitoring the penetration of pdms compounds into cotton fibres. Carbohydr Polym, 2013; 96(1):305-313.

Mohamed AL, Er-Rafik M, Moller M. Supercritical carbon dioxide assisted silicon based finishing of cellulosic fabric: A novel approach. Carbohydr Polym, 2013; 98(1): 1095-1107.
Mohamed AL, Hassabo AG. 2015. Flame retardant of cellulosic materials and their composites. In Visakh PM, Arao Y (Eds.).Flame retardants: Springer International Publishing (p.^pp.).

Mohamed AL, Hassabo AG, Nada AA, Zaghlool S. Encapsulation of nicotinamide into cellulose based electrospun fibres. Journal of Applied Pharmaceutical Science, Accepted 2016; Manuscript Number: JAPS-2015-11-569.

Moustafa SM, Menshawi BM, Wassel GM, Mahmoud K, Mounier MM. Screening of some plants in egypt for their cytotoxicity against four human cancer cell lines. International Journal of PharmTech Research, 2014; 6(3):1074-1084.

Nada AA, Hassabo AG, Awad HM, Fayad W, Shaffie NM, Sleem AA, Zeid NYA. Biomaterials based on essential fatty acids and carbohydrates for chronic wounds. Journal of Applied Pharmaceutical Science, 2015; $5(10($ Suppl 3)):13-21.

Nada AA, James R, Shelke NB, Harmon MD, Awad HM, Nagarale RK, Kumbar SG. A smart methodology to fabricate electrospun chitosan nanofiber matrices for regenerative engineering applications. Polymers for Advanced Technologies, 2014; 25(5):507-515.

Nolte DL, Barnett JP. A repellent to reduce mouse damage to longleaf pine seed. Int. Biodeterior. Biodegrad., 2000; 45(3-4):169-174.

Paolino D, Ventura CA, Nistico S, Puglisi G, Fresta M. Lecithin microemulsions for the topical administration of ketoprofen: Percutaneous adsorption through human skin and in vivo human skin tolerability. Int $\mathbf{J}$ Pharm, 2002; 244(1-2):21-31.

Peusch M, Müller-Seitz E, Petz M, Müller A, Anklam E Extraction of capsaicinoids from chillies (capsicum frutescens 1.) and paprika (capsicum annuum 1.) using supercritical fluids and organic solvents. Zeitschrift für Lebensmitteluntersuchung und -Forschung A, 1997; 204(5):351-355.

Sass NL, Rounsavill M, Combs H. A high-yield method for the extraction and purification of capsaicin. J Agric Food Chem, 1977; 25(6):1419-1420.

Tigner JR, Besser JF. Rodent repellency, a quantitative method for evaluating chemicals as rodent repellents on packaging materials. $\mathrm{J}$ Agric Food Chem, 1962; 10(6):484-486.

Tomasino C. 1992. Chemistry and technology of fabric preparation and finishing. Raleigh, North Carolina: North Carolina State University.

Visakh P, Arao Y. 2015. Flame retardants: Polymer blends, composites and nanocomposites. Springer.

Wagner CE, Cahill TM, Marshall PA. Extraction, purification, and spectroscopic characterization of a mixture of capsaicinoids. J Chem Educ, 2011; 88(11):1574-1579.

Waly AI, Abou-Zeid NY, Marie MM, El-Sheikh MA, Mohamed AL. Special finishing of cotton to impart flame-retardancy, easy care finishing and antimicrobial properties. Research Journal of Textile and Apparel, 2009; 13(3):10-26.

Waly AI, Marie MM, Abou-Zeid NY, El-Sheikh MA, Mohamed AL. Processes of dyeing, finishing and flame retardancy of cellulosic textiles in the presence of reactive tertiary amines. Research Journal of Textile and Apparel, 2012; 16(3):66 - 84.

\section{How to cite this article:}

Nada AA, Hassabo AG, Mohamed AL, Mounier MM, Zeid NYA. Liposomal Microencapsulation of Rodent-repelling Agents onto Jute Burlaps: Assessment of Cytotoxicity and Rat Behavioral Test. J App Pharm Sci, 2016; 6 (08): 142-150. 